УДК 811.161.2:33'75

DOI: https://doi.org/10.17721/APULTP.2021.43.125-147

\author{
Andriy $V$. Botsman \\ ORCID ID: 0000-0003-3083-6637 \\ Olga V. Dmytruk \\ ORCID ID: 0000-0002-7540-7708 \\ Valeria $V$. Bondarenko \\ ORCID ID: 0000-0001-5004-9855
}

\title{
MODELLING OF THE ANALYTICAL DEVELOPMENT OF THE GOTHIC FUTURE TENSE FORM
}

\begin{abstract}
The purpose of this article is to give the model, which demonstrates the development of the Future tense forms in the Gothic language. The initial stage of modelling the Future tense development includes the description of components according to their constituent features. It gives the possibility of tracing the gradual analytisation of corresponding grammatical form, and finding out latent features, which are characteristic for differentiated grammatical forms creating and building the set of Germanic future tense formal structures. The subject of the investigation are peculiarities of formation mechanism of temporal verb forms for projecting the action into the future. To describe the future action the Gothic language used forms of the Present tense involving phrase or upper phrase context. Within the Present tense forms a prefixal word formation model was found. The Greek future tense was translated involving prefixal and present forms in the Gothic language. The Gothic optative was involved to render the future tense. The present tense forms gain future meaning under the influence of aspect-tense specificity, which is recognized as futurelizing factor. Functions of the aspect-tense specificity may be performed with phrase or upper phrase context and syntactical structures with definitely represented semantics. Distinguished present tense constructions create the primary pivot, which is a basis for further development of the Gothic future tense forms. Gothic analytical structures with participle or infinitive were formed involving inchoative, strong, preterite present verbs. These structures are recognized as compound verbal predicates. Analytical structures cover the pivot creating coaxial cylinders. The whole model may be recognized as divergent-rotational because representing the Gothic future tense forms model itself "moves" along the temporal axis. Multilevel model structure demonstrates the fact that analytical forms are changeable in the gravitation. The comparison of divergent-rotational model components and peculiarities of their
\end{abstract}


arrangement indicates and the caudal development of the Future tense forms in the Gothic language. Tendencies found and distinguished as initial, primary in the Gothic language happen in the process of development of the Old Germanic languages. These tendencies are reflected in the Modern Germanic languages, too.

Key words: analytical form, aspect-tense specificity, futurelizing factor, inchoative verb, preterite-present verb, strong verb, synthetical form.

Information about the authors: Botsman Andriy Vasylovych - Ph.D. in Chemistry, Ph.D. in English Philology, Associate Professor; Associate Professor of the Department of English Philology and Intercultural Communication; Educational and Scientific Institute of Philology; Taras Shevchenko National University of Kyiv.

Dmytruk Olga Viktorivna - Ph.D. in English Philology, Associate Professor; Associate Professor of the Department of English Philology and Intercultural Communication; Educational and Scientific Institute of Philology; Taras Shevchenko National University of Kyiv.

Bondarenko Valeria Valeriivna - Ph.D. in English Philology, Associate Professor; Associate Professor of the Department of English Philology and Intercultural Communication; Educational and Scientific Institute of Philology; Taras Shevchenko National University of Kyiv.

E-mail:a.botsman@knu.ua; o.dmytruk@knu.ua; v.bondarenko@knu.ua.

Боцман А.В.

ORCID ID: 0000-0003-3083-6637

Дмитрук О.В.

ORCID ID: 0000-0002-7540-7708

Бондаренко В.В.

ORCID ID: 0000-0001-5004-9855

\title{
МОДЕЛЮВАННЯ АНАЛІТИЧНОГО РОЗВИТКУ ФОРМ ГОТСЫКОГО МАЙБУТНЬОГО ЧАСУ
}

\begin{abstract}
Анотація. Метою иієї статті $\epsilon$ створення моделі, яка демонструє розвиток форми майбутнього часу в готській мові. Початковою стадією моделювання розвитку майбутнього часу є опис складників відповідно до їх базових ознак. Це надає можливість відслідкувати проиес поступової аналітизаиї відповідних граматичних форм та здійснити пошук прихованих властивостей, що є характерними для виокремлення граматичних форм, що створюють $i$ вибудовують систему германських майбутніх часів. Предметом дослідження $\epsilon$ особливості та механізм формування часових дієслівних форм, що проектують дію у майбутнє. Для опису
\end{abstract}


майбутньої дії готська мова використовувала форми теперішнього часу, залучаючи фразовий або надфразовий контекст. У межсах форм теперішнього часу була виокремлена префіксальна модель. Грецький футурум перекладався у готських текстах, залучаючи префіксальну модель $i$ форму теперішнього часу. Майбутній час перекладався за допомогою готського активу. Форми теперішнього часу набували майбутнього значення під впливом видо-часовою специффікаиії, яка вбачалася узагальнюючим футуролізуючим чинником. Функиї футуралізуючих чинників (а фактично, видо-часової специфікачіі) можуть реалізовуватися у фразовому або надфразовому контексті та синтаксичних структурах 3 чітко окресленою семантикою. Виокремлення конструкиії та позначення теперішнього часу формують первісний осьовий стрижень, щчо слугує основою для подальшого розвитку готських форм на позначення майбутнього часу. Готські аналітичні структури на основі дієприкметника або інфінітива були сформовані шляхом залучення інхоативних, сильних $i$ претерито-презентних дієслів. Ці структури визначаються як складені дієслівні присудки. Аналітичні структури вкривають, охоплюють основний стрижень, формуючи коаксіальні ииліндри. У загальних обрисах модель може бути визначена як дивергентноротаційна, оскільки, репрезентуючи форми готського майбутнього часу, сама модель "рухається" вздовж темпоральної осі. Багаторівнева структура моделі демонструє той факт, що аналітичні форми змінюється у полі тяжіння стрижня. Порівняння компонентів дивергентну ротачійного моделі та особливості їхнього розташування вказує на каузальний розвиток форм майбутнього часу у готській мові. Тенденції, щзо віднайдені і кваліфіковані як ініціальні, первинні в готській мові, спостерігаються у процесі розвитку давньогерманських канських мов. Ці тендениії знаходять своє відображення і у сучасних германських мовах.

Ключові слова: аналітична форма, видо-часова особливість, інхоативні дієслова, претерито-презентне дієслово, сильно дієслово, синтетична форма, футуралізуючий чинник.

Інформація про авторів: Боиман Андрій Васильович - кандидат філологічних наук, кандидат хімічних наук, доцент; доцент кафедри англійської філологї та міжкультурної комунікачї; Навчальнонауковий інститут філологї; Київський національний університет імені Тараса Шевченка.

Дмитрук Ольга Вікторівна - кандидат філологічних наук, дочент; доиент кафедри англійської філології та міжкультурної комунікації; Навчально-науковий інститут філологї̈; Київський національний університет імені Тараса Шевченка.

Бондаренко Валерія Валеріївна - кандидат філологічних наук, доиент; доцент кафедри англійської філологї та міжкультурної 
Актуальні проблеми української лінгвістики: теорія і практика

комунікації; Навчально-науковий інститут філологї; Киӥвський начіональний університет імені Тараса Шевченка.
Електронна
aдpeca:
a.botsman@knu.ua;
o.dmytruk@knu.ua;

v.bondarenko@knu.ua.

Боцман А.В.

ORCID ID: 0000-0003-3083-6637

Дмитрук О.В.

ORCID ID: 0000-0002-7540-7708

Бондаренко В.В.

ORCID ID: 0000-0001-5004-9855

\section{МОДЕЛИРОВАНИЕ АНАЛИТИЧЕСКОГО РАЗВИТИЯ ФОРМ ГОТСКОГО БУДУЩЕГО ВРЕМЕНИ}

Аннотация. Целью данного исследования является создание модели, демонстрирующей развитие форм будущего времени в готском языке. Начальной стадией моделирования развития будущего времени является описание составляющих согласно их базовым признакам. Это дает возможность проследить прочесс постепенной аналитизации соответствующих грамматических форм $u$ осуществить поиск скрытых признаков, характерных для дифференцированных грамматических форм, которые создают и выстраивают систему германских будущих времён. Предметом исследования являются особенности и механизмы формирования темпоральных глагольных форм, проецирующих действие в будущее. Для описания будущего действия готский язык использовал формы настоящего времени, вовлекая фразовый или надфразовый контекст. В пределах форм настоящего времени была выделена префиксальная модель. Греческое будущее время переводилась в готских текстах $c$ использованием префиксальной модели и форм настоящего времени. Будущее время передавалась с помощью готского желательного наклонения (оптатива). Формы настоящего времени приобретали значение будущего времени под влиянием видовременной спецификации, которая определялась как обобщающий футурализирующий фактор. Функции футурализирующего фактора (а фактически, видовременной спецификачии) могут реализоваться во фразовом или надфразовом контекстах и соответствующих синтаксических структурах $c$ чётко очерченный семантикой. Выделенные конструкиии для обозначения настоямего времени формируют первичный основной стержень, который служит фундаментом для дальнейтего развития городских форм, 
обозначающий будущее время. Готские аналитические структуры на основе причастия или инфинитива были сформированы путём вовлечения инхоативных, сильных и претерито-презентных глаголов. Эти структуры определяются как составные глагольные сказуемые. Аналитические конструкиии покрывают, охватывают основной стержень, формируя как сочиальные иилиндры. В общем плане модель может быть определена как дивергентно-ротационная. Представляя формы готского будущего времени, сама модель "движется" вдоль временной оси. Многоуровневая структура модели демонстрирует тот факт, что аналитические формы меняются в поле притяжения стержня. Сравнение компонентов дивергентно-ротационный модели и особенности их развития указывают на каузальный характер трансформации форм будущего времени в готском языке. Тенденции, обнаруженные и квалифицированные как инициальные, исходные, первичные в готском языке происходят в прочессе развития древнегерманских языков. Эти же тенденции прослеживаются в современных германских языках.

Ключевые слова: аналитическая форма, видо-временная особенность, инхоативный глагол, претерито-презентный глагол, сильный глагол, синтетическая форма, футурализирующий фактор.

Информация об авторах: Боиман Андрей Васильевич -кандидат филологических наук, кандидат химических наук, дочент; дочент кафедры английской филологии и межкультурной коммуникации; Учебно-научный институт филологии; Киевский национальный университет имени Тараса Шевченко.

Дмитрук Ольга Викторовна - кандидат филологических наук, дочент; доцент кафедры английской филологии и межкультурной коммуникачии; Учебно-научный институт филологии; Киевский национальный университет имени Тараса Шевченко.

Бондаренко Валерия Валериевна - кандидат филологических наук, дочент; доцент кафедры английской филологии и межкультурной коммуникачии; Учебно-научный институт филологии; Киевский национальный университет имени Тараса Шевченко.

Электронный адрес: a.botsman@knu.ua; o.dmytruk@knu.ua; v.bondarenko@knu.ua.

The creation of the model which demonstrates the development of the Future tense forms within the cognate Germanic languages enables to find out the status and functional semantic specificity of the constituents distinguished, and peculiarities of their interaction and substitution. It demonstrates the necessity of differentiating, describing, classifying the components according to their constituent features. This action may be recognized as the primary, initial stage 
of modelling the future tense development. The main benefit of the model creation is the possibility of tracing, outlining, the appropriateness of external and internal aspects, which may be found in the diachronic comparison of the Germanic languages against the background of gradual analytization of corresponding grammatical forms.

The aim of the research is to describe the process of modelling, which caused the formation of different analytical form variants for representing Germanic future tense. The objective of this investigation is to find out latent features, which are characteristic of differentiated grammatical forms creating and building up the corpus of Germanic future tenses. The topicality of the research is connected with the fact that the investigation is not focused on the reconstruction of "archetype system", however, there is an attempt to reconstruct the order of stages connected with the formation of structures representing future tenses. The novelty of the present study is the attempt to restore the process order of forming the structures for future tense representation. Analytical forms demonstrate features of anaplasia and the whole process of the future form development looks caudal. The object of the investigation is a set of facts of the Gothic language compared with the corresponding Greek language patterns. This comparison helps to single out initial grammatical forms used for representing Germanic (Gothic) future, understand their functional stress and distinguish the most productive patterns. The subject of the investigation is the peculiarities, formation mechanism of temporal verb forms for projecting the action into the future and inner cooperation of the specified structures.

Publication analysis. The research of the Germanic languages is carried out comparing the East, West and Northern areas. It is believed that some isoglosses unite the Goths with the Scandinavians according to their character of genetic resemblance, other more numerous glosses unite the old Scandinavian dialects (except Gothic) with the West Germanic dialects. This common character appeared because of contacts between Scandinavian and West Germanic tribes. These contacts were possible using narrow channels and 
islands of the Jutland archipelago (it happened later when the Goths left that area and the Angles and Saxons did not leave for Britain, between $\mathrm{I}$ and $\mathrm{V}$ cent. A.D. [1, p. 430]). The attempt at reconstructing the peculiarities of Germanic future tense development (as any grammatical phenomena) should take into consideration the fact that any grammatical description, synchronic or diachronic, will be incomplete or one-sided if it is restructured with frames of classical lexical patterns involving flexion as it was in the XIX and at the very beginning of XX century. The investigation will be incomplete of the paradigmatic patterns grasp only analytical forms. Only the comprehensive and detailed selection of all completely or partly grammaticalized complex forms that exist in the language and observed in its development enable us to give complete and exhaustive notion about the language system as a dynamic and changeable formation.

The analytical construction development in the language is a movable and flexible process, which needs stage analysis and investigation in the diachronic and synchronic development. From the linguistic point of view, it means the refusal from separate and segregated investigation into synchronic and diachronic aspects. The language should be studied as a movable system which constantly changes in its separate parts and the whole. Dynamic approach indicates different levels of grammaticalization in analytical constructions. It calls for special attention to the intermediate forms which reflect the dynamic specificity of language in its development [8, p. 14].

Aspect-tense system of the Old Germanic languages is represented only with grammatical category of tense, where there is the opposition past tense $\because:$ present tense (preterite $\because:$ praesent). From the typological point of view this elementary system is in opposition to the developed systems of the modern Germanic languages with their new analytical verb forms. It constitutes the biggest part of flexion forms [2, p. 20-21].

According to the common and general tradition the initial stage, which needs no further explanation, of the Germanic aspect-tense system is the stage which is reflected in the oldest Germanic 
languages, first of all the Gothic language. Within the limited chronological frames of research all the changes that occurred in the Germanic aspect-tense system are represented as a one-way process with broadening and complication of morphological opposition. It to emphasize that this process occurs under the conditions of relative stability of the old type of word-forming markers which were involved in the aspect-tense system [5, p. 146-147]. Analytical formulas (if we compare the diachronic mutual relations of case forms and prepositional phrases) are involved into the paradigm [2, p. 22]. That is why researchers' attention is focused on the semantic structure of the inherited system. It is the sphere where researchers should find out common for the Germanic languages' morphological evolution conditions, which caused the parallel development of basic lines [6, p. 231].

Elements, which are used more regularly, such as Gothic compositions, correlate with simple verb forms not only involving direct simple positional contacts. It is not the task of a researcher to try to understand systemic non-obligation of using the peripheral element as arbitrariness of simple and marked form divisions in texts. There was an attempt to formulate rules about the usage of ga-composita and simplicia in different syntactical context $[10, \mathrm{p}$. 30]. When the language has elements containing aspect-tense feature, it causes the narrowing of the simple form sphere usage. All that indicates the potential possibilities of fixing the morphological opposition [2, p. 29]. All the facts mentioned above should be taken into consideration when the model of the Germanic future tense is built up.

The main point which is worth mentioning is the fact that tense forms of the Greek and Gothic languages don't coincide when the Gospel texts are compared. There is a complex system of different correlations. There was a conventional correlation when every correlative unit obtained known principal meaning (dominant meaning), but the same meaning occurred in other competitive forms. All these correlations looked very unstable and fragile $[9, \mathrm{p}$. 168]. Difficulties of comparison are connected with the fact that within all Germanic languages the Gothic language had the least 
developed system of tenses except separate individual and very specific cases. There were no tendencies of translation to the precise tense indication as it occurred in the manuscripts of Old High German, Old Saxon and Anglo-Saxon [7, p. 120].

Main information presentation. In order to represent the future action, the Gothic language used forms of the present tense (Vpraes. ind.). The concretization of the future meaning of these present forms was provided involving phrase on upper-phrase context. That context contained either specific lexico-semantic indicators or indirect indicators - indications of aspect-tense process peculiarities: in pizai ustassai, pan ussatandand harjamma ize wairpip qens? (Mk. XII, 23)" in the resurrection therefore whose wife shall she be?" Within the present tense forms there is a prefixal word formation model $g a+$ Vpraes. Verbs belonging to that model are identified according to W. Streitberg's ideas as go-composita [6, p. 41], and that prefixal structure is used for the Greek future tense representation in the Gothic language: ik qimands gahailjai ina (M. VIII, 7) "[and said to him,]" I shall come and heal him." Qipanu izwis patei gedaupnip in frawaurhtim iz waraim (J. VIII, 24) "I said therefore to you, that you shall die in your sins." qibandan ina, patei ik gataira alh po handuwaurhton (Mk. XIV, 58) "Him say, "I shall destroy this temple made with hands." ip gaggip swintoza mis, pizei ik ni im wairts and bindan skaudaraip skohis is; sah izwis daupeip in ahmin weihamma jah funin habands wintiskauron, in handau seinai jah gahra ieip gaprask sein jah briggip (simplex tantum) kurn in bansta seinamme (L. III, 16-17) "One is coming who is mightier than I, and I am not fit to untie the thong of His sandals; He will baptize you with the Holy Spirit and fire. And His winnowing fork in His hand to thoroughly clear His threshing floor, and to gather the wheat into His barn." Simple forms gahraineips are recognized as imperfect, but their temporal correlation may be different. It may coincide (daupeip) or not coincide (im, gaggif) with ga-composita correspondence. The Greek future tense may be translated involving ga-composita and present form (Vpraes) simultaneously (ga-Vpraes

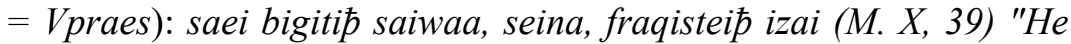
who has found his life shall lose it." This correlation may be fixed in 
the equation $g a+$ Vpraes $=$ Vpraes ind. It is necessary to take into consideration that Gothic verb lexical meaning proper (its "aspectual distinction semantics") is weakly differentiated and lacks the ability to limit the aspect-tense correlation of verb forms.

In the Gothic language there is an opposition between two classes of verbs: non-conclusive class and neutral class not indicating the non-conclusiveness. There are no durative verbs here. All honconclusive verbs may describe processes represented with the context devices as continuous without approaching their aim, goal (in particular, simultaneously to the moment of speaking [2, p. 30]: sai qimith heila jah nu qam, ei distahjada harjizuh duseinaim (J. XVI, 32) "Behold, an hour is coming, and has already come, for you to be scattered, each to his own home." The word building model ga + Vpraes is the leading structure among aspect-tense elements. Correlation ga-composita/simplicia (ga + Vpraes / Vpraes ind) grasps the biggest portion of verb corpus (244 verbs with preverb gain 2516 usage cases. It promotes the preverb semantic differentiation and testifies to the existence of general grammatical meaning. Structures ga-composita are known not to be qualified as special forms of verb paradigm $[11$, p. 205]. Their paradigmatic status contradicts two facts. The first one is connected with the verbs which don't correlate to ga-composita. The second one demonstrates the dependence of that upon the meaning of lexical groups including simple verbs (simplicia) [4, p. 217].

The Gothic optative synthetic structure (Vopt praes) has the same grammatical meaning as analytical structures in other Germanic languages. These analytical structures are discrete morphemes spanning modal (preterite-present) verbs and verbals. They may be used in contrast with the present tense forms of the Indicative mood (Vpraes ind): ik im Gabriel sa standands in andwaittjja gudis... jah sai sija is pahands jah ni magands rodjan (L. I, 19-20) "I am Gabriel, who stands in the presence of God;... and behold, you shall be silent and unnable to speak..." There are cases of contrast using the synthetic structures with the form of participle I $(V p)$ which indicates the action simultaneous to the moment of speech: $a \not \hbar a n s a$ 
drobjands izwis sa bairai po wargita (Gal. V, 10) "but the one who is disturbing you shall bear his judgment."

The Gothic future action is represented by three synthetic present forms: Vpraes ind, ga-Vpraes, Vopt praes. Present tense forms gain future meaning under the influence of apect-tense specificity. In this case it is recognized as a futurelizing factor. Functions of the aspect-tense specificity may be performed with phrase or upper-phrase context and syntactical structures with definitely represented semantics. At first it is seen in the Adverbial Subordinate Clauses of time / condition where the verb-predicate having future meaning is used in the present tense form: $i k$ skal waurkjan waurstwa... unte dags is (J. IX, 4) "I shall work as long as it is day." jah jabai qeøjau நatei ni kunnjau ina, sijau galeiks izwis liugnja (J. VIII, 55) "and if I say that I do not know Him, I shall be a liar like you." The same phenomenon occurs in the Adverbial Clauses of place: padei ik gagga, jus ni magü quiman (J. VIII, 21): "where I am going, you cannot come."

Stability and constancy of using the present forms with explicit future meaning in the Adverbial Clauses of condition is confirmed by the Modern West Germanic and North Germanic languages where this specific usage may be observed till now. It confirms the fact of the aspect-tense specificity influence on the tense form of the verbpredicate till how. The semantic influence of the Adverbial Subordinate Clauses is enough for representing future meaning, therefore the present form remains unchangeable.

Distinguished present tense constructions create a primary pivot which is a basis for further development of Germanic future tense forms (Fig. 1). This pivot is formed along the temporal axis and consists of three basic segments Vpraes ind, ga-Vpraes, Vopt praes, all three are closely connected with one another creating stable thorough structure. Pivotal forms show certain resistance to the usage of analytical forms in Adverbial Clauses of Condition and Time. Reciprocity and correlation of the three identified components enable the formation of that monolithic pivotal construction which may be characterized as futuralistic synthetical present. 
The use of the Gothic mediopassive (which was only in the present form [3, p. 195]) for representing Greek future tense may be observed from two different points of view. From the first point of view Gothic mediopassive may be recognized as broadening the synthetic form devices (synthetic forms include Vpraes, Vopt). From the opposite point of view the mediopassive usage for future action description may be recognized as the first step to the gradual transition from synthetical to analytical forms. It is explained by the fact that in order to represent the passive meaning the Gothic language had synthetic mediopassive and periphrastic constructions:

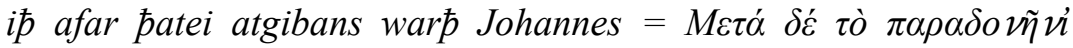
I $\omega \alpha \dot{\nu} \nu \eta v(M k . I, 14)$ "and after John had been taken into custody."

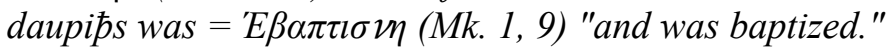

The use of the opposition Vactive / Vmediopassive is very demonstrative to the preference of Vmediopassive when the future meaning is described: jah ni stojid, eini stojandau, ni afdomjaid, jah ni afdomjanda, fraletaid, jah fraletanda (L. VI, 37) "and do not judge and you will not be judged; and do not condemn, and you will not be condemned; pardon, and you will be pardoned." Sense structure of mediopassive having the future tense projection gains clear outline

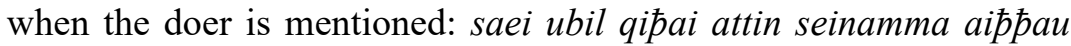
aipein seinal, dauநau afdaupjaidau (Mk. VII, 10) "He who speaks evil of father or mother, let him be put to death." The same sense structure occurs in the context without naming the doer: gibaid, jah gibada izwis (L. VI, 38) "Give, and it will be given to you." ip atgaggand dagos, pan afnimada af im sa brupfaps (M. IX, 15) "But the days will come when the bridegroom is taken away from them, and then they will fast." all bagme ni taujandane akran god usmaitada jah in fon altagjada (M. VII, 19) "every tree that does not bear good fruit is cut down and thrown into the fire." This fact shows that the Gothic present tense is a colony forming unit. The outline of that unit broadens because there are two constituents involved, the first is the present tense, active voice form and the second is mediopassive. The present form boundaries broaden as the pluripotential (temporal) precursor $\left[\begin{array}{lll}3 & \text { p. 64 }\end{array}\right]$, because the 
mediopassive involvement means its usage for representing present and future tense.

In the case of opposition Vpraes / Vmediopas, the last form is preferable for rendering Greek future tense. As Gothic mediopassive is a synthetic form, it gravitates towards the structure of synthetic pivot, but Vmediopas is not the segment pivotal constituent, it creates cylindrical cover over the pivot. This cylindrical cover is not complete solid, but discrete, "semi-transparent" (Fig. 1). In a very formal way, it demonstrates the belonging of Vmediopas to the synthetic forms; but simultaneously underlines its indefiniteness, approximateness for rendering the future tense meaning. This indefinite position in the formal structure underlines the fact of the equivalent analytical form existence for rendering passive and future meaning. Among all Germanic languages Gothic had the biggest number of forms for representing subject inactivity (latent passive). These forms include mediopassive (Vpraes mediopas), which was only in the present tense, verbs of the IV class that competed with particular constructions in representing future meaning [9, p. 224]. It explains the very rare usage of participial constructions with the present form of wairpan. Those constructions had very definite future projection wairpan + Vp: jah wairpand allai laisidai gudis (J. VI, 45) "and they shall be taught of God." This analytical structure may be recognized as a combined element. It has separate features of perfect and duration. The common meaning of the construction is inchoative, it indicates the intersection of the initial point of the durative process-state.

Combinations of present form wairpan $+V p$ are synonymous to combinations duginnan $+V i n f$, in the formal way it is shown as wairpan $+V p .=$ duginnan + Vinf: $\operatorname{saurgandans}$ wairpip $(J . X V I, 20)$ "you will weep and lament." faginon duginna (Ph. I, 18) "and I will rejoice." It testifies to the fact that this lexical syntactical mode as a certain type of the compound predicate gains some polyfunction. This polyfunction is revealed in the passive meaning (the subject's inactivity is indicated) that approximates the model to the Gothic mediopassive (duginnan + Vinf. $\Rightarrow$ Vpraes mediopas). Both structures belong to the elements with future action indication. 
Comparing all the data and adding structural elements on the pivotal model makes visible the of the unit wairtan $+V p$, which indicates the Gothic future action. This unit cannot belong to the pivot (where Vpraes ind, ga-Vpraes, Vopt praes occur) or gain the position of Vpraes mediopas. This unit belongs to the analytical form and cannot be connected with the synthetic pivot. Units with analytical forms cover the pivot creating coaxial cylinders. The unit wairpan $+V p$ creates which is a coaxial cylinder next to the pivot, which is covered with the "semi-transparent" cylindrical cover Vpraes mediopas. These two units having different structural nature have common passive meaning. Analyzing these two units with some approximation and conditional character, it is possible to notice a subtle transition of future elements from synthetic form Vpraes mediopas to the prototype of perspective analytical forms wairpan + $V p$. The latter form has the synonymic combination duginnan + Vinf, approaching it to the inchoative structures.

Analytical structure formed with the infinitive and phase (inchoative) verb (duginnan $+\operatorname{Vinf}$ ) occurs only two times and in the contrast position: wai izwis, jus hlahjandans nu, unte gaunon jah gretan duginnid (L.VI, 25) "Woe unto you that laugh now! for ye shall mourn and weep," compare also (Ph. I, 19). Incoherence of future tense elements along with minor importance of their tense function are seen in their ability of combining. The final meaning of a combined element (as in other cases wairpan $+V p$ ) is summarized from the meaning of elements, which are involved into the analytical form. It is noticeable in the comparison of the models use ga-Vpraes + Vopt in the position of contrast with the simple element Vopt: jah jabai sijai jainar sunnus gawairpijp, gaheilaitp sik ana imma gawairpi izwar (L. X, 6) "and if a man of peace is there, your peace will rest upon him." Similar meaning is rendered with the combination wairban +Vopt (L. I, 20).

Against the background of instability there is an intermediate structure, which may be qualified as a transitional element between synthetical and analytical temporal forms. The germs of that transition are seen in the Gothic mediopassive, which was an isolated synthetical form and was sporadically used for indicating future 
action. Taking into consideration the fact that the Gothic mediopassive did not have any corresponding synthetical reflection in other Old Germanic languages, this transitional connection is very subtle and conventional. The identified primary forms of analytical passive of the Old Germanic languages were sporadically used to represent future meaning. It is possible to speak about the semantic approximation of the Gothic mediopassive, but the structural unity (from one point synthetical, from the opposite point analytical) is out of consideration.

Returning to the pivotal model, it is possible to represent the structure with the inchoative verb as a coaxial cylinder that has the combination duginna $+\operatorname{Vinf}($ Fig. 1). As the units wairpan $+V p$ and duginna + Vinf have semantic resemblance, the distance between their formal coaxial cylinders (their sides) should be minimal. Analytical forms, which were created involving infinitive and strong or preterite-present verbs (Vstrong + Vinf; Vpraet praes + Vinf; $h a b a+$ Vinf; skal + Vinf), are rare and their meaning is indicated to Vopt praes. Maybe, these analytical forms are more expressive. In three cases out of six ones (all of them correspond to the Greek future tense) temporal contrast of processes (which are indicated with the word combination and non-marked tense form) is underlined with the similarity of both verbs haba = skal: patei jah rodja du izwis, manag skal bi izwis rodjah jah stojan (J.VIII, 25) "what have I been saying to you from the beginning I have many things to speak and judge concerning you." The same example with haban is in (th. II, 4). The following example demonstrates the parallel usage of analytical structure haban + Vinf, with synthetical structure Vopt: jah parei im ik, paruh sa andbahts meins wisan habaip; jah jabai has mis andbahtheił swerjaitp ina atta (J. XII, 26) "and where I am, there shall My servant also be; if anyone serves Me, the Father will honor him." 


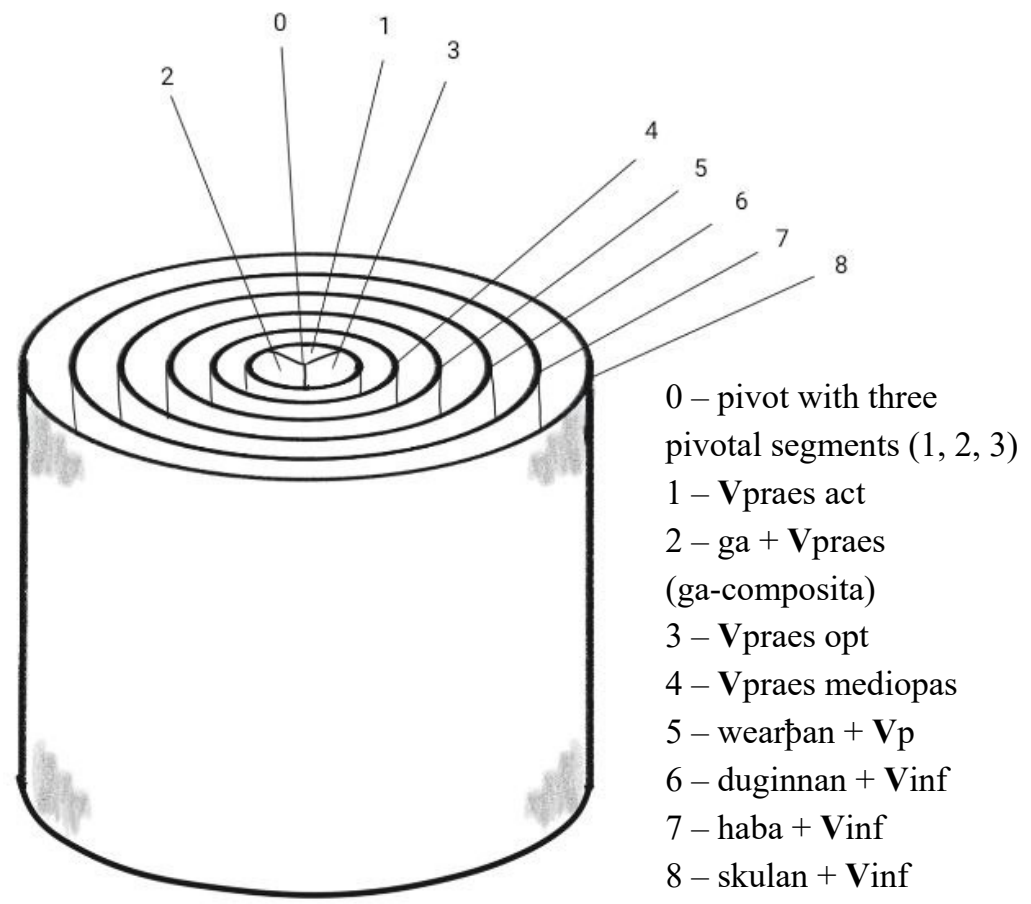

Fig. 1. Pivotal-coaxial model of the future tense form development in the Gothic language

The structure Vstrong + Vinf. (haban + Vinf) is represented with a coaxial cylinder, the same cylinder may be used for modelling the structure Vpraet-praes $+\operatorname{Vinf}($ skal + Vinf). The formal model demonstrating the development of Germanic Future Tense includes a temporal future pivot, which is covered with the set of coaxial cylinders. The whole model may be recognized as divergentrotational because representing the structures of Germanic (Gothic) future tense forms the whole model "moves" along the temporal axis. Analytical future tense forms are modelled as a set of coaxial cylinders, their sides are created with analytical components, which rotate the future tense axis different orbits - distances. The Vmediospas "glides" on the surface of the pivot as a synthetic form. 
Випуск XLIII

The scheme of distinguishing the Gothic future tense forms demonstrates all possible forms for Future tense representation in the Gothic language, giving detailed description of all components. All the peculiarities are shown in Fig. 2.

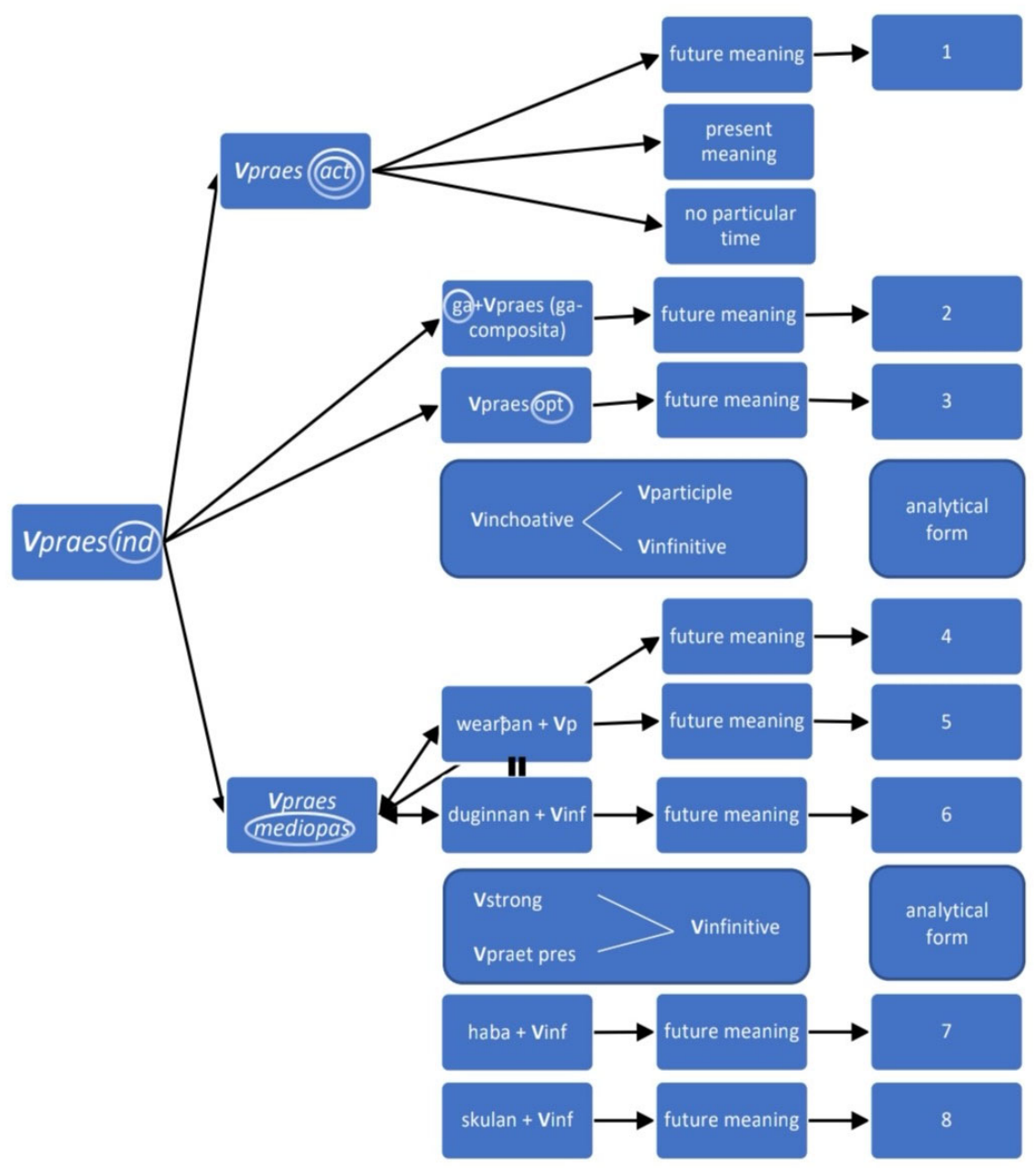

Fig. 2. The scheme of distinguishing the Gothic future tense forms 
Conclusion and further investigation. Gothic texts demonstrate isolated instances of descriptive forms, which have future tense meaning. It is difficult to indicate the most frequent forms as they occur rarely in the Gothic texts, and their preterite-present primary semantics prevents from understanding and recognizing the preferences connected with their usage when the future tense is described. As other Old Germanic languages demonstrate the most frequent structure with two preterite present verbs, which had been fixed in Gothic - wiljan, skulan - and in some languages these verbs have parallel (nearly equivalent) usage, it may be supposed that their latent semantics was the best for indicating Old Germanic future. The Gothic language demonstrates the involvement of inchoative verbs (in the present tense form) to signify future action (Vinchoat + Vinf). With some supposition the structure Vinchoat + Vinf may be recognized as one of the links between synthetical and analytical forms. Inchoative verb usage testifies to the fact that in the process of its development the system of future tense created variants of analytical forms which within the simple sentence were able to substitute one another, but within the complex sentence analytical forms were not able to resist the force of future semantics of present forms. It was supported by futurelizing factor of Adverbial clauses of time and condition.

The question arises why not all inchoative and preterite-present verbs were involved in creating analytical future forms. Partly, it may be explained with the pivotal model. In the pivotal model the central position belongs to the axis-pivot. There are analytical structures around that pivot. Around the axis-pivot there is gravitation which involves only the verbs whose semantics corresponds to the future projection. That is why only some separate inchoative and preterite-present verbs are involved into this model. It is necessary to take into consideration the influence of futurelizing factors. These factors grasp Adverbial Modifiers of time within the simple sentence, and the semantics of Adverbial Clauses of time and condition. In the latter case the Adverbial Clause semantics is enough, and the additional usage of analytical (preterite-present) forms in the Adverbial Clauses transforms futurelizing factors into 
superfluous, excessive ones. That is why Analytical future as an innovative formation did not develop in the Adverbial Clauses.

Multi-level model structure demonstrates the fact that analytical forms in the gravitation of pivot are changeable. They may function simultaneously underlining grammatical category of person in the subject, type of clause, and may disappear under certain conditions changing Future tense paradigm into the minimal quality of component (zullen in Dutch, skall in Swedish). The comparison of divergent-rotational model components and the peculiarities of their arrangement demonstrates the casual development of future tense forms in the Germanic languages. Tendencies found and distinguished as initial, primary in the Gothic language happen in the process of development of all Old Germanic languages. These tendencies are reflected in the Modern Germanic languages, too.

Having certain vacations on the way of their historical development, all Germanic languages demonstrated the analytization of future tense forms, simultaneously preserving synthetic structures in the simple and subordinate clauses. Analytical forms are created with inchoative and preterite-present verbs. This stage differs in the West Germanic languages. The High German language got its specificity using the inchoative verb. Other West Germanic languages had common features with the Scandinavian languages, they preferred preterite-present verbs. That morphological common feature confirms the fact of contact between Germanic tribes in the area of the Jutland archipelago separated from the peninsular of Scandinavia with harrow channels. The contact weakening between the Low German and High German dialects is demonstrated with the variation of analytical future.

Table 1 sums up morphological features of the Gothic verb in the process of its involvement into the representation of the future tense This table demonstrates the gradual development of the analytical forms. When the primary synthetical forms pass from the active voice into mediopassive, the transitional form occurs. This transitional form being unstable and uncertain shifts the equilibrium into the stable position which is associated with analytical forms. These forms gain further stability removing the mediopassive and 
using more stable and certain active. Analytical forms inherit the involvement of the primary present tense for finite verb components.

Table 1. Morphological characteristics of the Gothic future tense forms

\begin{tabular}{|c|c|c|c|c|c|c|}
\hline $\begin{array}{c}\text { Type of the } \\
\text { tense form }\end{array}$ & Voice & Mood & \multicolumn{2}{|c|}{ Tense } & \multicolumn{2}{|c|}{ Pattern } \\
\hline synthetic(al) & active & $\begin{array}{c}\text { indicative } \\
\text { optative }\end{array}$ & present & \multicolumn{2}{|c|}{$\begin{array}{c}\text { Vpraes act } \\
\text { Vpraes opt }\end{array}$} \\
\hline $\begin{array}{c}\text { synthetic(al) } \\
\text { (transitional) }\end{array}$ & mediopassive & indicative & present & \multicolumn{2}{|c|}{ Vmediopas praes } \\
\hline analytical & active & indicative & $\begin{array}{c}\text { finite } \\
\text { verb } \\
\text { present }\end{array}$ & $\begin{array}{c}\text { non- } \\
\text { finite } \\
\text { verb }\end{array}$ & $\begin{array}{c}\text { Vinchoative } \\
\text { Vstrong } \\
\text { Vpreter-pr }\end{array}$ & + \\
Vp \\
Vinf
\end{tabular}

Table 2 demonstrates the driving forces causing the development of the analytical future tense forms. These forces were engendered by the binary private opposition. The opposition occurred on three different levels characterizing the Gothic verb. Each level contains two correlated elements forming the oppositional relationship. Mood level grasps indicative $\rightarrow$ optative components. Voice level contains active $\rightarrow$ mediopassive components. Form level is represented with synthetical $\rightarrow$ analytical forms. Cooperation of these three levels brought about the further development of analytical forms. These forms bear subtle features of inner form opposition, too. It means that within any analytical form there is a semi-opposition between the personal form verb and non-personal one. The first element losing its lexical meaning was transformed into the auxiliary verb, the marker of the future tense meaning. The second element preserved its primary lexical meaning, but was represented as a verbal (non-personal form). Their inner opposition (or semiopposition) initiated the grammaticalization as a necessary stage of analytical form creation. The three level opposition relations involved undeveloped morphological forms. The optative mood and mediopassive voice were not on the high level of development and were developed later to the oblique mood and passive voice in the West and North Germanic languages in the middle and new periods. 
Table 2. Three-level binary private opposition causing the formation of the Gothic future tenses

\begin{tabular}{|c|c|}
\hline Verb characteristic & Correlated elements \\
\hline Mood & indicative : : optative \\
\hline Voice & active $:$ mediopassive \\
\hline Form & synthetic(al) : : analytical \\
\hline
\end{tabular}

The comparison of Table 2 data leads to the conclusion of compensative mechanism, which caused the introduction of the analytical morphological forms. In the column of correlated elements, the left ones (optative, mediopassive) belong to the underdeveloped forms. Their defectiveness, underdevelopment, subtle morphological features are compensated by the analytical elements, which possess future tense meaning. The lack of functional effectiveness in optative and mediopassive forms for representing future was compensated by the vast development of analytical forms suitable for future tense representation.

In the process of adapting the synthetic forms for representing future tense these forms pass through unstable positions (optative, mediopassive), gaining further stability in active, indicative features of newly created analytical forms. It may be demonstrated using the patterns of Table 3. It sums up the transformation and changings of morphological peculiarities that took place under the influence of stability factors. Gothic analytical innovation for future tense representation gets its stability in principal clauses or simple sentences. Gothic traditional synthetic forms for future tense (preterite-futurum) representation are preserved in adverbial clauses of time and condition, under the influence of phrase and upper phrase contexts. All of them together are recognized as a set of stabilizing factors. Synthetical-transitional unstable forms, which grasp mediopassive and optative, move towards stability. The stability may be reached with the regressive movement back, when the synthetical forms remain in their future meaning, functioning in adverbial clauses of time and condition. This type of stability may be classified as absolute. It happens in all Modern Germanic languages without any exception. Another type of stability may be reached involving 
the progressive movement forward when analytical forms are introduced in simple sentences and principal clauses.

Table 3. Stabilizing factors of the future tense development

\begin{tabular}{|c|c|c|c|}
\hline $\begin{array}{c}\text { Type of the } \\
\text { state }\end{array}$ & stable & unstable & stable \\
\hline $\begin{array}{c}\text { Type of the } \\
\text { form }\end{array}$ & synthetic(al) & $\begin{array}{c}\text { synthetic(al) }- \\
\text { transitional }\end{array}$ & analytical \\
\hline Voice & active & mediopassive & active \\
\hline Mood & indicative & optative & indicative \\
\hline $\begin{array}{c}\text { Stabilizing } \\
\text { factor }\end{array}$ & $\begin{array}{c}\text { aspect-tense specification } \\
\text { futurelizing factor } \\
\text { adverbial clauses of } \\
\text { condition, time }\end{array}$ & - & principal \\
clause
\end{tabular}

The whole system of figures (Fig. 1, Fig. 2) and tables (Table 1, Table 2, Table 3) demonstrates the ways of the future tense development in the Gothic language, which is a pattern indicating the general direction of the future temporal form transformation towards their analytization involving two-component models. Using the way of the Gothic future tense development modelling, the next highpotential step is to build up the model of the Old West and North Germanic languages, reflecting the specificity of the future form development. The specificity of the Gothic language future form development shows the phenomenon of anaplasia. The anaplasia is recognized as atypical additional differentiation of future tense forms. This atypical additional differentiation is the analytization of morphological future forms. The comparison of future forms of corresponding Old and Modern Germanic languages seems to have highly advantageous prospects and be informative for further research. It will help to understand the details of forming analytical temporal structures.

\section{REFERENCES}

1. Arntz, H. (1936). Gemeingermanisch. Germanen und Indogermanen Volkstum. Sprache, Heimat, Kultur, Festschrift für Herman Hirt. Heidelberg: Fachbuchverlag, 428-451 [in German]. 
2. Beheydt, G. (2005). The absolute and the relative present tense with future time reference in English and Dutch. Crosslinguistic View on Tense, Aspect and Modality. Amsterdam: Rodopi, 15-32 [in English].

3. Bannet, W. H. (1960). An Introduction to the bothic language. New York: Modern Language Association, 246 p. [in English].

4. Braune, W. (1981). Gotische Grammatik. 19. Auflage. Tübingen: Max Niemeyer Verlag, 384 s. [in German].

5. Brinkmann, H. (1931). Sprachwandel und Sprachbewengungen in althochdeutscher Zeit. Jeha: Friedrich Schiller Universität, 428 s. [in German].

6. Brugmann, K. \& Delbrück, B. (1897). Grundriß der vergleichenden Grammatik den indogermenischen Sprachen. Strassbung: Fachbuchverlag, 386 s. [in German].

7. Jellinek, M. H. \& Hermann, P. (2017). Geschichte der gotischen Sprache. Berlin, Boston: De Gruyter Mouton, 209 s. https://doi.org/ 10.1515/9783111446158 [in German].

8. Nevalainen, T. (2004). Three perspectives on grammaticalization: Lexico-grammar, corpora and historical sociolinguistics. Corpus Approaches to Grammaticalization in English. Amsterdam: John Benjamins, 1-31. https://doi.org/10.1075/scl.13.03nev [in English].

9. Rauch, I. (2003). The Gothic language: grammar, genetic provenance and typology reading. New York: P. Lang, 346 p. https://doi.org/ 10.29091/KRATYLOS/2005/1/52 [in English].

10. Sherer, Ph. (1964). The theory of the function of the Gothic preverb ga-. Word, 5, 39-45. [in English].

11. Wright, J. (1997). Grammar of the Gothic language. Oxford: Clarendon Press. 366 p. [in English].

Дата надходження до редакції - 30.08.2021 Дата затвердження редакцією - 27.09.2021 